\title{
Co-operatives and Agricultural Development: A Study in Sathyamangalam Block of Erode District
}

\author{
P. Shanmugam ${ }^{1 *}$ and N. Arivazhagan ${ }^{2}$ \\ ${ }^{1}$ Assistant Professor, Department of Economics, Bharathiar University, Coimbatore - 641046, Tamil Nadu, India; \\ bushanmugam@gmail.com \\ ${ }^{2}$ M.Phil., Research Scholar, Department of Economics, Bharathiar University, Coimbatore - 641046, Tamil Nadu, India
}

\begin{abstract}
India is primarily based on agriculture in which more than half of its population is dependent for their livelihood. Even though the share of agriculture in GDP is decreasing due to industrialization, its development is inevitable. The most important issue that hurdles the development of agriculture is finance. Among the various sources of raising finance for agriculture, institutional finance plays an important role. In this regard, the present study aims to analyze the role of co-operative societies in promoting agricultural development in Sathyamangalam block of Erode District. The land holding pattern, details of loan amount availed, cropping pattern, awareness towards lending pattern of co-operative societies and the major determinants of amount of loan availed are also examined.
\end{abstract}

Keywords: Agricultural Finance, Co-operatives, Cropping Pattern, Lending Pattern

\section{Introduction}

The role of finance in agriculture is crucial like any other sectors. Agricultural finance helps the farmers to undertake new investments or to adopt new technologies in farming $\stackrel{1}{1}$. Since the beginning of planning period, the emphasis on agricultural credit is exorbitant which fosters the agricultural growth and development. The various financial institutions promoted by the Government help the farmers to avail credit facilities. Among the financial avenues, the co-operative societies have a significant role in the development of agriculture as it provides loans and advances at the convenience of the farmers. In this aspect, the present study is an attempt to analyze the role of co-operative societies in the development of agriculture in Sathyamangalam block of Erode District.

\section{Statement of the Problem}

India is an agriculture country. Most of the people depend on agricultural sector. The purpose of agriculture is not only to increase the agricultural production but also to increase export capacity. It also improves foreign exchange. Agriculture production requires timely and sufficient supply of essential inputs. Most of the farmers are poor and they cannot have enough money to meet purchase of seeds, recommended dose of fertilizers, hiring farm machinery, etc. So lack of finance is one of the main reasons for low productivity in agriculture. The agricultural financing encourage the farmers to use modern technologies and secure input for farm use. The co-operative banks are the most important avenue which provides agricultural finance to the farmers for meeting their capital requirements. This paper focuses on the role played by Erode District Central Co-operative Bank in agricultural financing through crop loans.

\section{Review of Literature}

Suryawansi $\mathrm{i}^{2}$ observed that big farmers received a larger share of loan advanced by different financial agencies and the share of co-operatives was the maximum. Niranjanraj and Chitanbaram ${ }^{3}$ suggested that the performance of co-operative banks should not be measured in terms

*Author for correspondence 
of financial/ economic achievements only but their performance should also be evaluated. Satyasai and Badatya $\mathrm{a}^{4}$ analyzed the performance of rural co-operative credit institutions on the basis of borrowings and lending operations, cost structure and financial viability. It was found that co-operative system, in general, had failed to perform its functions properly. Nair ${ }^{5}$ observed that during 1951-2001, the PACs made rapid strides in membership, owned funds, deposits and in channelizing the production credit for farmers. Veni and Sah ${ }^{6}$ opined that the growth rate of Co-operative Banks is relatively lower than the SCBs and RRBs in terms of short-term, long-term and total credits. Shah Deepak ${ }^{\underline{7}}$ conducted a case study of Sangli and Buldana District Central Co-operative Banks, regarding the financial health of credit co-operatives in Maharashtra and found NPA or over-dues as the main culprit for the deterioration in the health of these banks. Government of India ${ }^{-}$stated that the co-operative plays a vital role in the rural livelihood. It was suggested that plans have to be implemented in doubling the income of the farmers by 2022 by reducing the cost of cultivators for which the co-operative were to play an important role.

\section{Objectives of the Study}

To know the socio-demographic and economic characteristics of the respondents.

$>$ To examine the awareness of respondents towards lending pattern of co-operative societies.

$>$ To find out the major determinants of loan amount in the study area.

\section{Methodology}

The study is descriptive and analytical. Survey method is followed for the collection of data. Both primary and secondary sources of data are collected for the study. There are 163 Primary Agricultural Co-operative Societies (PACS) functioning in Erode District, Tamil Nadu. All these PACS were functioning under the Administrative Control of Circle Deputy Registrars of Co-operative Societies, viz. Sathyamangalam Circle. From the Sathyamangalam Circle 2 PACS were purposively selected for the study based on their performance. For representing Circle Deputy Registrar of Co-operative Societies the Periur (with highest number of beneficiaries) PACS and Maranoor (with lowest number of beneficiaries) PACS are selected purposively. The data regarding Membership, Share Capital, Deposit Mobilization, Borrowings, Working Capital, Loan Operations, Income, Business Strategies adopted etc., are collected from the respective PACS. The data collected were reduced to tables for analysis and interpretation. For understanding the perception of farmers $15 \%$ of the existing members of the sample PACS are selected by adopting Simple Random Sampling method. Thus, the total sample farmers are 99, including 61 from Periur and 38 from Maranoor.

\section{Hypothesis}

$\mathrm{H}_{0}$ : The cropping income and operational holding does not have impact on the loan amount.

\section{Results and Discussion}

\subsection{Socio-demographic and Economic Profile of the Respondents}

The respondents are classified based on their socio-demographic and economic characteristics and are analyzed by using Simple Percentage Analysis. The results are shown in Table 1.

Table 1. Distribution of the Respondents Based on Socio-Demographic and Economic Characteristics

\begin{tabular}{|c|c|c|c|c|}
\hline \multirow{2}{*}{ S. No. } & \multirow{2}{*}{ Categories } & \multicolumn{2}{|c|}{ Branch } & \multirow{2}{*}{ Total } \\
\hline & & Periur & Maranoor & \\
\hline \multicolumn{5}{|l|}{ Age } \\
\hline 1 & Below 35 & $\begin{array}{c}7 \\
(11.48)\end{array}$ & $\begin{array}{c}1 \\
(2.63)\end{array}$ & $\begin{array}{c}8 \\
(8.08)\end{array}$ \\
\hline 2 & $35-60$ & $\begin{array}{c}53 \\
(86.89)\end{array}$ & $\begin{array}{c}37 \\
(97.37)\end{array}$ & $\begin{array}{c}90 \\
(90.91)\end{array}$ \\
\hline \multirow[t]{2}{*}{3} & Above 60 & $\begin{array}{c}1 \\
(1.64)\end{array}$ & $\begin{array}{c}0 \\
(0.0)\end{array}$ & $\begin{array}{c}1 \\
(1.01)\end{array}$ \\
\hline & Total & $\begin{array}{c}61 \\
(100.0)\end{array}$ & $\begin{array}{c}38 \\
(100.0)\end{array}$ & $\begin{array}{c}99 \\
(100.0)\end{array}$ \\
\hline \multicolumn{5}{|c|}{ Gender } \\
\hline 1 & Male & $\begin{array}{c}50 \\
(81.97)\end{array}$ & $\begin{array}{c}30 \\
(78.95)\end{array}$ & $\begin{array}{c}80 \\
(80.81)\end{array}$ \\
\hline \multirow[t]{2}{*}{2} & Female & $\begin{array}{c}11 \\
(18.03)\end{array}$ & $\begin{array}{c}8 \\
(21.05)\end{array}$ & $\begin{array}{c}19 \\
(19.19)\end{array}$ \\
\hline & Total & $\begin{array}{c}61 \\
(100.0)\end{array}$ & $\begin{array}{c}38 \\
(100.0)\end{array}$ & $\begin{array}{c}99 \\
(100.0)\end{array}$ \\
\hline \multicolumn{5}{|c|}{ Type of Family } \\
\hline 1 & Joint & $\begin{array}{c}23 \\
(37.70)\end{array}$ & $\begin{array}{c}14 \\
(36.84)\end{array}$ & $\begin{array}{c}37 \\
(37.37) \\
\end{array}$ \\
\hline \multirow[t]{2}{*}{2} & Nuclear & $\begin{array}{c}38 \\
(62.30)\end{array}$ & $\begin{array}{c}24 \\
(63.16)\end{array}$ & $\begin{array}{c}62 \\
(62.63)\end{array}$ \\
\hline & Total & $\begin{array}{c}61 \\
(100.0)\end{array}$ & $\begin{array}{c}38 \\
(100.0)\end{array}$ & $\begin{array}{c}99 \\
(100.0)\end{array}$ \\
\hline
\end{tabular}




\begin{tabular}{|c|l|c|c|c|}
\hline \multirow{2}{*}{ S. No. } & \multirow{2}{*}{ Categories } & \multicolumn{2}{|c|}{ Branch } & \multirow{2}{*}{ Total } \\
\cline { 3 - 4 } & & Periur & Maranoor & \\
\hline \multicolumn{3}{|c|}{ Literacy Level } \\
\hline \multirow{2}{*}{1} & $\begin{array}{l}\text { No formal } \\
\text { Education }\end{array}$ & $\begin{array}{c}26 \\
(42.62)\end{array}$ & $\begin{array}{c}20 \\
(52.63)\end{array}$ & $\begin{array}{c}46 \\
(46.46)\end{array}$ \\
\hline 2 & $\begin{array}{l}\text { Primary } \\
\text { Level }\end{array}$ & $\begin{array}{c}27 \\
(44.26)\end{array}$ & $\begin{array}{c}16 \\
(42.11)\end{array}$ & $\begin{array}{c}43 \\
(43.43)\end{array}$ \\
\hline 3 & College & 8 & 2 & 10 \\
& Level & $(13.11)$ & $(5.26)$ & $(10.10)$ \\
\hline \multirow{2}{*}{ Total } & & $\begin{array}{c}61 \\
(100.00)\end{array}$ & $\begin{array}{c}38 \\
(100.00)\end{array}$ & $\begin{array}{c}99 \\
(100.00)\end{array}$ \\
\hline
\end{tabular}

Source : Computed. Figures in parentheses are percentages to the total

Table 1 discloses that in Periur, a maximum of $86.89 \%$ of the respondents are in the age group of $35-60$ years, $81.97 \%$ of the respondents are male, $62.30 \%$ of the respondents belong to nuclear family and $44.26 \%$ of the respondents has primary level of education. In Maranoor, a maximum of $97.37 \%$ of the respondents are in the age group of $35-60$ years, $78.95 \%$ of the respondents are male, $63.16 \%$ of the respondents belong to nuclear family and $46.46 \%$ of the respondents does not have any formal education.

\subsection{Land Holding Pattern by the Respondents}

The land holding pattern by the respondents in Periur and Maranoor is shown in Table 2 and is analyzed with Simple Percentage Analysis.

Table 2. Distribution of the Respondents Based on Land Holding Pattern

\begin{tabular}{|c|l|c|c|c|}
\hline \multirow{2}{*}{$\begin{array}{c}\text { S. } \\
\text { No. }\end{array}$} & \multirow{2}{*}{$\begin{array}{c}\text { Land Holding } \\
\text { Pattern }\end{array}$} & \multicolumn{2}{|c|}{ Branch } & \multirow{2}{*}{ Total } \\
\cline { 3 - 4 } 1 & Up to 1 Acre & $\begin{array}{c}4 \\
(6.56)\end{array}$ & $\begin{array}{c}5 \\
(13.16)\end{array}$ & $\begin{array}{c}9 \\
(9.09)\end{array}$ \\
\hline 2 & $1-2$ Acres & $\begin{array}{c}27 \\
(44.26)\end{array}$ & $\begin{array}{c}14 \\
(36.84)\end{array}$ & $\begin{array}{c}41 \\
(41.41)\end{array}$ \\
\hline 3 & $2-3$ Acres & $\begin{array}{c}23 \\
(37.70)\end{array}$ & $\begin{array}{c}12 \\
(31.58)\end{array}$ & $\begin{array}{c}35 \\
(35.35)\end{array}$ \\
\hline 4 & $3-4$ Acres & $\begin{array}{c}6 \\
(9.84)\end{array}$ & $\begin{array}{c}6 \\
(15.79)\end{array}$ & $\begin{array}{c}12 \\
(12.12)\end{array}$ \\
\hline 5 & Above 4 Acres & $\begin{array}{c}1 \\
(1.64)\end{array}$ & $\begin{array}{c}1 \\
(2.63)\end{array}$ & $\begin{array}{c}2 \\
(2.02)\end{array}$ \\
\hline & Total & $\begin{array}{c}61 \\
(100.00)\end{array}$ & $\begin{array}{c}38 \\
(100.00)\end{array}$ & $\begin{array}{c}99 \\
(100.00)\end{array}$ \\
\hline
\end{tabular}

Source: Computed. Figures in parentheses are percentages to the total.

It is found from Table 2 that majority of the respondents hold 1-2 acres of land both in Periur (44.26\%) and Maranoor (36.84\%) followed by $37.70 \%$ of the respondents holding 2-3 acres of land in Periur and $31.58 \%$ of the respondents holding 2-3 acres of land in Maranoor.

\subsection{Quantum of Loan Applied and Availed by the Respondents}

The amount of loan applied and availed by the respondents varies from one another based upon many factors. The Table 3 reveals the details of quantum of loan applied and availed by the respondents in Periur and Maranoor analysed by using Simple Percentage Analysis.

Table 3. Distribution of the Respondents Based on Quantum of Loan Applied and Availed

\begin{tabular}{|c|c|c|c|c|}
\hline \multirow{2}{*}{ S. No. } & \multirow{2}{*}{ Factors } & \multicolumn{2}{|c|}{ Branch } & \multirow{2}{*}{ Total } \\
\hline & & Periur & Maranoor & \\
\hline \multicolumn{5}{|c|}{ Quantum of Loan Applied (Rs.) } \\
\hline 1 & Below 50000 & $\begin{array}{c}0 \\
(0.00)\end{array}$ & $\begin{array}{c}2 \\
(5.26)\end{array}$ & $\begin{array}{c}2 \\
(2.02)\end{array}$ \\
\hline 2 & $50000-100000$ & $\begin{array}{c}28 \\
(45.90) \\
\end{array}$ & $\begin{array}{c}12 \\
(31.58)\end{array}$ & $\begin{array}{c}40 \\
(40.40)\end{array}$ \\
\hline 3 & $100000-150000$ & $\begin{array}{c}26 \\
(42.62)\end{array}$ & $\begin{array}{c}19 \\
(50.00)\end{array}$ & $\begin{array}{c}45 \\
(45.45)\end{array}$ \\
\hline 4 & $150000-210000$ & $\begin{array}{c}6 \\
(9.84)\end{array}$ & $\begin{array}{c}4 \\
(10.53)\end{array}$ & $\begin{array}{c}10 \\
(10.10)\end{array}$ \\
\hline \multirow[t]{2}{*}{5} & Above 210000 & $\begin{array}{c}1 \\
(1.64)\end{array}$ & $\begin{array}{c}1 \\
(2.63)\end{array}$ & $\begin{array}{c}2 \\
(2.02)\end{array}$ \\
\hline & Total & $\begin{array}{c}61 \\
(100.0)\end{array}$ & $\begin{array}{c}38 \\
(100.00)\end{array}$ & $\begin{array}{c}99 \\
(100.00)\end{array}$ \\
\hline \multicolumn{5}{|c|}{ Quantum of Loan Availed (Rs.) } \\
\hline 1 & Below 40000 & $\begin{array}{c}6 \\
(9.84) \\
\end{array}$ & $\begin{array}{c}7 \\
(18.42)\end{array}$ & $\begin{array}{c}13 \\
(13.13)\end{array}$ \\
\hline 2 & $40000-50000$ & $\begin{array}{c}21 \\
(34.43)\end{array}$ & $\begin{array}{c}7 \\
(18.42)\end{array}$ & $\begin{array}{c}28 \\
(28.28)\end{array}$ \\
\hline 3 & $50000-60000$ & $\begin{array}{c}6 \\
(9.84)\end{array}$ & $\begin{array}{c}6 \\
(15.79)\end{array}$ & $\begin{array}{c}12 \\
(12.12)\end{array}$ \\
\hline 4 & $60000-70000$ & $\begin{array}{c}16 \\
(26.23)\end{array}$ & $\begin{array}{c}13 \\
(34.21)\end{array}$ & $\begin{array}{c}29 \\
(29.29)\end{array}$ \\
\hline \multirow[t]{2}{*}{5} & Above 70000 & $\begin{array}{c}12 \\
(19.67)\end{array}$ & $\begin{array}{c}5 \\
(13.16) \\
\end{array}$ & $\begin{array}{c}17 \\
(17.17)\end{array}$ \\
\hline & Total & $\begin{array}{c}61 \\
(100.0)\end{array}$ & $\begin{array}{c}38 \\
(100.00)\end{array}$ & $\begin{array}{c}99 \\
(100.00)\end{array}$ \\
\hline
\end{tabular}

Source: Computed. Figures in parentheses are percentages to the total.

Table 3 discloses that the majority of $45.90 \%$ of the respondents in Periur has applied for Rs.50000-Rs. 100000 in PACS and $50 \%$ of the respondents in Maranoor has applied for a loan of Rs. 100000-Rs. 150000. Further, maximum of $34.43 \%$ of the respondents in Periur availed Rs. 40000 -Rs. 50000 and $34.21 \%$ of the respondents availed Rs. 60000- Rs. 70000 in Maranoor. 


\subsection{Cropping Pattern and Income of the Respondents}

The respondents in the study areas are engaged in cultivating various crops in their land namely Paddy, Sugarcane, Turmeric and Banana. The classification of the respondents based on the cropping pattern is shown in Table 4 by analyzing with Simple Percentage Analysis.

Table 4. Distribution of the Respondents Based on Cropping Pattern and Income

\begin{tabular}{|c|l|c|c|c|}
\hline \multirow{2}{*}{ S. No. } & \multicolumn{1}{|c|}{ Crop } & \multicolumn{2}{|c|}{ Branch } & \multirow{2}{*}{ Total } \\
\cline { 3 - 4 } & Periur & Maranoor & \\
\hline 1 & Paddy & $\begin{array}{c}13 \\
(21.31)\end{array}$ & $\begin{array}{c}10 \\
(26.32)\end{array}$ & $\begin{array}{c}23 \\
(23.23)\end{array}$ \\
\hline 2 & Sugarcane & $\begin{array}{c}9 \\
(14.75)\end{array}$ & $\begin{array}{c}8 \\
(21.05)\end{array}$ & $\begin{array}{c}17 \\
(17.17)\end{array}$ \\
\hline 3 & Turmeric & $\begin{array}{c}18 \\
(29.51)\end{array}$ & $\begin{array}{c}12 \\
(31.58)\end{array}$ & $\begin{array}{c}30 \\
(30.30)\end{array}$ \\
\hline 4 & Banana & $\begin{array}{c}21 \\
(34.43)\end{array}$ & $\begin{array}{c}8 \\
(21.05)\end{array}$ & $\begin{array}{c}29 \\
(29.29)\end{array}$ \\
\hline \multirow{2}{*}{ S.No. } & Income (Rs.) & $\begin{array}{c}61 \\
(100.00)\end{array}$ & $\begin{array}{c}38 \\
(100.00)\end{array}$ & $\begin{array}{c}99 \\
(100.00)\end{array}$ \\
\hline 1 & Periur & Maranoor & Total \\
\hline 2 & $100000-200000$ & $\begin{array}{c}28 \\
(45.90)\end{array}$ & $\begin{array}{c}2 \\
(31.58)\end{array}$ & $\begin{array}{c}2 \\
(42.02)\end{array}$ \\
\hline 3 & $200000-300000$ & $\begin{array}{c}28 \\
(45.90)\end{array}$ & $\begin{array}{c}21 \\
(55.26)\end{array}$ & $\begin{array}{c}49 \\
(49.49)\end{array}$ \\
\hline 4 & Above 300000 & $\begin{array}{c}5 \\
(8.20)\end{array}$ & $\begin{array}{c}3 \\
(7.89)\end{array}$ & $\begin{array}{c}8 \\
(8.08)\end{array}$ \\
\hline & Total & $\begin{array}{c}61 \\
(100.00)\end{array}$ & $(100.00)$ & $\begin{array}{c}99 \\
(100.00)\end{array}$ \\
\hline
\end{tabular}

Source: Computed. Figures in parentheses are percentages to the total.
Table 4 evinces that more number of $34.43 \%$ of the respondents in Periur cultivate Banana followed by Turmeric (29.51\%) and $31.58 \%$ of the respondents cultivate Turmeric followed by Paddy (26.32\%). The majority of the respondents in Periur (45.90) earned an income of Rs.100000-Rs.300000 whereas majority of the respondents in Maranoor (55.26\%) earned an income of Rs. 200000-Rs. 300000.

\subsection{Awareness towards Lending Pattern of PACS}

The awareness of the respondents towards lending pattern and the consequences of non-repayment of loan are studied with 3 point scaling by categorizing as Aware, Doubtful and Unaware. The distribution of the respondents based on their level of awareness is examined with Simple Percentage Analysis and is shown in Table 5.

Table 5 reveals that in Periur, majority of the respondents are aware of the consequences such as panel interest on outstanding, disqualifies voting, disqualifies any position, attachment of properties, leads to legal action, affects the social status, disturbs refinancing, forbids other farmers, increased overdue and financial burden. Further, number of the respondents is doubtful with regard to default payment ineligibility. In Maranoor, majority of the respondents are aware of all the consequences namely default payment ineligibility, panel interest on outstanding, disqualifies voting, disqualifies any position, attachment of properties, leads to legal action, affects the social status, disturbs refinancing, forbids other farmers, increased overdue and financial burden.

Table 5. Awareness of the Beneficiaries on Lending Pattern and Consequences of Non-Repayment of Loan

\begin{tabular}{|c|c|c|c|c|c|c|c|c|}
\hline \multirow{3}{*}{ S. No. } & \multirow{3}{*}{$\begin{array}{l}\text { Awareness and } \\
\text { Consequences }\end{array}$} & \multicolumn{6}{|c|}{ Branch } & \multirow{3}{*}{ Total } \\
\hline & & \multicolumn{3}{|c|}{ Periur } & \multicolumn{3}{|c|}{ Maranoor } & \\
\hline & & Aware & Doubtful & Unaware & Aware & Doubtful & Unaware & \\
\hline 1 & $\begin{array}{l}\text { Default payment } \\
\text { ineligibility }\end{array}$ & $\begin{array}{c}25 \\
(40.98)\end{array}$ & $\begin{array}{c}26 \\
(42.62)\end{array}$ & $\begin{array}{c}10 \\
(16.39)\end{array}$ & $\begin{array}{c}20 \\
(52.63)\end{array}$ & $\begin{array}{c}10 \\
(26.32)\end{array}$ & $\begin{array}{c}8 \\
(21.05)\end{array}$ & $\begin{array}{c}99 \\
(100.00)\end{array}$ \\
\hline 2 & $\begin{array}{l}\text { Panel Interest on } \\
\text { outstanding }\end{array}$ & $\begin{array}{c}28 \\
(45.90)\end{array}$ & $\begin{array}{c}23 \\
(37.70)\end{array}$ & $\begin{array}{c}10 \\
(16.39)\end{array}$ & $\begin{array}{c}24 \\
(63.16)\end{array}$ & $\begin{array}{c}8 \\
(21.05)\end{array}$ & $\begin{array}{c}6 \\
(15.79)\end{array}$ & $\begin{array}{c}99 \\
(100.00)\end{array}$ \\
\hline 3 & Disqualifies Voting & $\begin{array}{c}30 \\
(49.18)\end{array}$ & $\begin{array}{c}25 \\
(40.98)\end{array}$ & $\begin{array}{c}6 \\
(9.84)\end{array}$ & $\begin{array}{c}25 \\
(65.79)\end{array}$ & $\begin{array}{c}8 \\
(21.05)\end{array}$ & $\begin{array}{c}5 \\
(13.16)\end{array}$ & $\begin{array}{c}99 \\
(100.00)\end{array}$ \\
\hline 4 & Disqualifies any Position & $\begin{array}{c}32 \\
(52.46) \\
\end{array}$ & $\begin{array}{c}24 \\
(39.34) \\
\end{array}$ & $\begin{array}{c}5 \\
(8.20) \\
\end{array}$ & $\begin{array}{c}26 \\
(68.42) \\
\end{array}$ & $\begin{array}{c}7 \\
(18.42) \\
\end{array}$ & $\begin{array}{c}5 \\
(13.16) \\
\end{array}$ & $\begin{array}{c}99 \\
(100.00) \\
\end{array}$ \\
\hline 5 & Attachment of properties & $\begin{array}{c}34 \\
(55.74) \\
\end{array}$ & $\begin{array}{c}23 \\
(37.70) \\
\end{array}$ & $\begin{array}{c}4 \\
(6.56) \\
\end{array}$ & $\begin{array}{c}27 \\
(71.05) \\
\end{array}$ & $\begin{array}{c}7 \\
(18.42) \\
\end{array}$ & $\begin{array}{c}4 \\
(10.53) \\
\end{array}$ & $\begin{array}{c}99 \\
(100.00) \\
\end{array}$ \\
\hline
\end{tabular}




\begin{tabular}{|c|c|c|c|c|c|c|c|c|}
\hline \multirow{3}{*}{ S. No. } & \multirow{3}{*}{$\begin{array}{l}\text { Awareness and } \\
\text { Consequences }\end{array}$} & \multicolumn{6}{|c|}{ Branch } & \multirow{3}{*}{ Total } \\
\hline & & \multicolumn{3}{|c|}{ Periur } & \multicolumn{3}{|c|}{ Maranoor } & \\
\hline & & Aware & Doubtful & Unaware & Aware & Doubtful & Unaware & \\
\hline 6 & Leads to legal action & $\begin{array}{c}35 \\
(57.38) \\
\end{array}$ & $\begin{array}{c}22 \\
(36.07) \\
\end{array}$ & $\begin{array}{c}4 \\
(6.56) \\
\end{array}$ & $\begin{array}{c}26 \\
(68.42) \\
\end{array}$ & $\begin{array}{c}8 \\
(21.05) \\
\end{array}$ & $\begin{array}{c}4 \\
(10.53) \\
\end{array}$ & $\begin{array}{c}99 \\
(100.00) \\
\end{array}$ \\
\hline 7 & Affects the social status & $\begin{array}{c}34 \\
(55.74)\end{array}$ & $\begin{array}{c}24 \\
(39.34)\end{array}$ & $\begin{array}{c}3 \\
(4.92)\end{array}$ & $\begin{array}{c}27 \\
(71.05)\end{array}$ & $\begin{array}{c}6 \\
(15.79)\end{array}$ & $\begin{array}{c}5 \\
(13.16)\end{array}$ & $\begin{array}{c}99 \\
(100.00)\end{array}$ \\
\hline 9 & Forbids other farmers & $\begin{array}{c}38 \\
(62.30)\end{array}$ & $\begin{array}{c}22 \\
(36.07)\end{array}$ & $\begin{array}{c}1 \\
(1.64)\end{array}$ & $\begin{array}{c}27 \\
(71.05)\end{array}$ & $\begin{array}{c}7 \\
(18.42)\end{array}$ & $\begin{array}{c}4 \\
(10.53)\end{array}$ & $\begin{array}{c}99 \\
(100.00)\end{array}$ \\
\hline 10 & Increased overdue & $\begin{array}{c}39 \\
(63.93) \\
\end{array}$ & $\begin{array}{c}23 \\
(37.70) \\
\end{array}$ & $\begin{array}{c}0 \\
(0.00) \\
\end{array}$ & $\begin{array}{c}28 \\
(73.68) \\
\end{array}$ & $\begin{array}{c}5 \\
(13.16) \\
\end{array}$ & $\begin{array}{c}5 \\
(13.16)\end{array}$ & $\begin{array}{c}99 \\
(100.00)\end{array}$ \\
\hline 11 & Financial burden & $\begin{array}{c}40 \\
(65.57)\end{array}$ & $\begin{array}{c}15 \\
(24.59)\end{array}$ & $\begin{array}{c}6 \\
(9.84)\end{array}$ & $\begin{array}{c}30 \\
(78.95)\end{array}$ & $\begin{array}{c}4 \\
(10.53)\end{array}$ & $\begin{array}{c}4 \\
(10.53)\end{array}$ & $\begin{array}{c}99 \\
(100.00)\end{array}$ \\
\hline
\end{tabular}

Source : Computed. Figures in parentheses are percentages to the total.

\subsection{Determinants of Loan Amount}

Table 8 discloses the analysis of major determinants of enrolment in loan amount. To find out the major determinants, a multiple linear regression model is used.
The amount of loan is taken as dependent variable and age, literacy level, type of family, caste, cropping income, rate of interest, area of land holding and type of crop are considered as independent variables.

Table 6. Determinants of Loan Amount- Multiple Linear Regression Model

\begin{tabular}{|c|l|c|c|c|c|}
\hline \multirow{2}{*}{ S. No. } & \multirow{2}{*}{ Independent Variables } & \multicolumn{2}{|c|}{ Coefficients } & \multirow{2}{*}{ t } & \multirow{2}{*}{ Sig } \\
\cline { 3 - 5 } & & B & Std. Error & & \\
\hline 1 & Constant & 20110.154 & 7570.135 & 2.657 & .009 \\
\hline 2 & Age & -219.712 & 147.750 & -1.487 & .140 \\
\hline 3 & Literacy Level & 1219.552 & 691.012 & 1.765 & .081 \\
\hline 4 & Type of Family & 2948.819 & 1195.410 & 2.467 & .016 \\
\hline 5 & Caste & -198.694 & 1074.735 & -.185 & .854 \\
\hline 6 & Cropping Income & .202 & .014 & 14.547 & .000 \\
\hline 7 & Interest Rate & -.114 & .191 & -.598 & .551 \\
\hline 8 & Area of Land Holding & 523.051 & 1213.636 & .431 & .668 \\
\hline 9 & Type of Crop & 1048.556 & 952.099 & 1.101 & .274 \\
\hline & R & $.927^{a}$ & & & \\
\hline & R Square & .859 & & & \\
\hline & F & 68.765 & & & 0.000 \\
\hline
\end{tabular}

Source: Computed

The F ratio 68.765 was significant at one percent level indicates that the construction of the model is good. The $\mathrm{R}^{2}$ value is 0.859 which represents that all the selected variables together influence the dependent variable by 86 percent. Before getting the final results, the multicollinearity test is also conducted and the variables with collinearity are ignored. Among the variables, type of family $(t=2.467)$ and cropping income $(\mathrm{t}=14.547)$ are significant at $5 \%$ level whereas the level of literacy of the farmers $(t=1.765)$ was significant at $10 \%$ level. Thus, the major determinants of loan amount are neither social nor economical and hence the hypothesis "The farm income and operational holding does not have an impact on the loan amount" is partially proved. 


\section{Suggestions}

As many farmers in the study area are of the opinion that the loan received by them is insufficient, they may be provided adequate loan to meet their agricultural requirement.

When the repayment period is short, the farmers could not repay the amount completely. Hence, the period of repayment may be increased by the PACS enabling the farmers to repay the loan amount without any burden.

$>$ The banking authorities should relax the formalities and procedures in availing loan by the farmers as most of the people do not have formal education. Further, the relaxation of cumbersome procedures will help the farmers in obtaining the required loan easily in time.

\section{Conclusion}

The present study analyses the role of co-operative finance for agriculture in Sathyamangalam block. Most of the farmers availed the loan for turmeric cultivation, but the size of loan is very small. The quantum of loan is determined by many factors of which total assets, possession of wet land and agricultural income are prominent. The co-operative finance plays a vital role in raising the agricultural income of the farmers as it is pivotal and promotes the agriculture to a greater extent. However, the farmers in the study areas are much bothered about the short duration of the loan for agricultural development. Hence, the co-operatives societies should solve such problems and promote agriculture and the farmers to a better position.

\section{References}

1. Pandey UK. An introduction to agricultural finance. Kalyani Publishers. New Delhi - Ludhiana. 1990. p. 196.

2. Suryawansi SD. Credit requirements, availability and its gap. Indian Journal of Agricultural Economics.1978:568.

3. Niranjanraj, Chitanbaram. Measuring the Performance of DCCBs. NAFSCOB Bulletin. 2000; 5(3).

4. Satyasai KJS, Badatya KC. Restructuring rural credit co-operative institutions. Economic and Political Weekly. 2000; 35(5):307-30.

5. Nair BR. Village Co-operatives - A century of service to the nation. Carlos. 2005.

6. Veni LK, Sah AN. Direct institutional credit to agriculture and allied activities-changing scenario. ICFAI Journal of Agricultural Economics, Hyderabad. 2005; 3:63-71.

7. Shah D. Evaluating financial health of credit co-operatives in Maharashtra State of India. MPRA Paper-3949 (July). University Library of Munich, Germany. 2007. 